\title{
COMMUNICATION STRATEGY OF DAKWAH IN COMMUNITY OF THE MODERN ERA (CASE STUDY IN LENGKONG VILLAGE, SUKOREJO DISTRICT, PONOROGO REGENCY)
}

\author{
Zaimatul Millah \\ Universitas Islam Negeri Sunan Kalijaga Yogyakarta \\ zaimatulmilla23@gmail.com
}

\begin{abstract}
Voicing goodness including preaching is an obligation for Muslims. In contrast to the method of preaching the Prophet Muhammad in the past, the ease of doing anything now cannot be separated because of the role of technological developments in disseminating information including preaching. The modern era provides an opportunity for us to invite us to do good by preaching by utilizing technology. However, the ease of access now is also inseparable from the communication strategy of preaching da'i in packaging da'wah messages to attractive and light da'wah methods which are also very much needed by modern society. In this paper the author presents empirical data from the preaching of the Prophet Muhammad which is still relevant to be implemented in the communication strategy of da'wah in modern society. The purpose of this research is that the modern era da'wah strategy must be able to be side by side with advanced science and technology. So that the use of technology in preaching is needed in order to increase faith and devotion to Allah through verbal communication (bil al-oral) and nonverbal (bil al hal). The result of this research is that modern society in Lengkong Village gives a good response and can apply what has been conveyed through the da'wah communication strategy carried out, by utilizing the sophistication of today's technology.
\end{abstract}

\section{Keywords: Strategy, Da'wah Communication, Society, Modern Era}

\section{INTRODUCTION}

Every religion in the world has a goal to spread the teachings of truth to all mankind. Islam in the spread of Islamic law has been started since the sending of the Prophet Muhammad SAW. Efforts to spread religious truth that comes from God as a sacred duty and devotion to God Almighty is called da'wah. Da'wah in essence calls to the way of Allah so that they believe is the obligation of every Muslim. Awareness of the importance of da'wah needs to be instilled in every Muslim, because this is a command from Allah SWT to humans with wisdom, good lessons, or by arguing in a better way.

The existence of Islam until now cannot be separated from the influence of da'wah. The first time preaching the teachings of Islam was brought by the Prophet Muhammad SAW, who at that time Islam was considered a new religion and was not 
simply accepted by the ignorant people. The acceptance of Islamic teachings by the community is of course with da'wah communication that is packaged attractively by the da'i or communicator in conveying so that the message can be well received. Conveying goodness that is general in nature is also part of da'wah, because essentially all goodness is embodied in the teachings of Islam.

Islamic da'wah as an activity and as a science cannot be separated from the development of communication technology. Communication is part of one of the influencing actions that can use a persuasive way. The purpose of persuasive communication within the framework of da'wah is communication that is always oriented to the psychological aspects of the mad'u (audience) in order to raise their awareness to accept and implement Islamic teachings. ${ }^{1}$ Spranger Allport, explained that there are six value orientations that are often used as references by humans in their lives. In its appearance, these six values tend to display a unique character towards a person's personality. Therefore, Spanger designed the value theory in terms of the types of man, which means that everyone has a stronger orientation to one of the six values contained in his theory. The six values in question are theoretical values, economic values, aesthetic values, social values, political values, and religious values. ${ }^{2}$

Religion is an order of life that integrates humans in community life. Many people do not feel proud if they are not religious and even feel offended by it. Religion is expected to be a motivation and dynamist of human life, making humans dynamic, tenacious, diligent, hard working and so on. Indicators of the success of da'wah in the era of globalization, information and the era of industrialization as said by Western historian W Montgomery Watt analyzing the secrets of the progress of Islam, he said that Islam does not recognize a rigid separation between science, ethics, and religious teachings, in other words Islam can also accept healthy (radical) thinking limited to the advancement of Islamic civilization and for the sake of enriching Islamic hasanah. One after another, executed in one breath. The practice of Islamic law is as important and has the same priority as scientific research. The

1 Wahyu Ilaihi. Komunikasi Dakwah (Bandung: PT. Remaja Rosdakarya, 2010). p. 205.

2 Muhammad Arif. Urgensitas Pesantren Dalam Inovasi Pendidikan (Kediri: IAIN KEDIRI PRESS, 2019). p. 12. 
indicator of the success of religion in this global transformation is if humans are able to find good wisdom and lessons in accordance with the object of da'wah in each of the teachings it carries. ${ }^{3}$

Actually, Islamic da'wah in the era of globalization does not contradict the science of religion and non-religion. In fact, da'wah must be able to create the Islamic religion as a motivator and dynamist for scientific development, hard work and even at the level of pious charity. In the era of globalization there will be many changes in people's lives, which will form a society rich in information. Islamic da'wah must also continue to be turned on according to the demands of the times with various developments of the times. ${ }^{4}$

The development of da'wah in this modern era must be in line with advances in science and technology and human civilization so that Islamic da'wah is able to color all aspects of human life. In the modern era like now, it is definitely a must for da'wah interpreters to take advantage of all existing forms of technology to facilitate the achievement of the goals and objectives of da'wah. Without utilizing the existing da'wah media, da'wah will not progress. Along with the development of science and technology that causes changes in various aspects of human life, both in terms of religion, politics and changes in tradition in modern society. 5

One of the da'wah activities that must be intensively carried out by da'wah interpreters and Islamic organizations is the Islamic development of rural communities in order to make Islam a way of life. Thus, the purpose of da'wah in rural communities is an effort to foster religious community so that the community understands its teachings and is able to practice the points of Islamic teachings in life comprehensively with a true and strong foundation of faith.

In order for the purpose of da'wah to be achieved, da'wah must be carried out regularly and directed. The implementation of a more regular and targeted

3 Istina Rahmawati. Potret Dakwah di Tengah Era Globalisasi dan Perkembangan Zaman (AT-TABSYIR, Jurnal Komunikasi Penyiaran Islam Vol. 1, No. 1, Januari - Juni 2013). p. 77.

${ }^{4}$ Ibid, p. 77-78.

${ }^{5}$ Asna Istya Marwantika, "TREN KAJIAN DAKWAH DIGITAL DI INDONESIA : SYSTEMATIC LITERATURE REVIEW," Proceeding of Conference on Strengthening Islamic Studies in The Digital Era 1, no. 1 (2021): 249-65, https://prosiding.iainponorogo.ac.id/index.php/ficosis/article/view/37. 
da'wah requires a process. In the stages of a process there are several terms such as approaches, strategies, methods, techniques and tactics. Approach is a point of view on a problem, approach refers to a view about the occurrence of a process that is still general in nature. Strategy is a strategic plan to achieve something. Method is a way to achieve something. Technique is a more specific way of applying a method while tactics is a person's way of carrying out a technique or method. ${ }^{6}$

In today's life, there have been many shifts in the values of human life, Islamic da'wah and the consolidation of religious teachings are absolutely necessary in reducing the life that has been infiltrated by ignorance in the global era and is considered very dangerous compared to the ignorance that existed before the Prophet. Finally, as people who live in the modern era, it is expected that Muslims with their da'wah must be able to coexist with advanced science and technology, by mastering the science and technology that is currently developing in addition to having strong faith and piety to Allah SWT. Therefore, as evidenced by current technological advances, the author is interested in conducting research on the implementation of the communication strategy of the Prophet's time preaching which is adapted to modern society in Lengkong Sukerojo Village, Ponorogo.

\section{RESEARCH METHODS}

The research method used by the author here is a qualitative descriptive research method. Descriptive research is a method that describes all data or the state of the subject or object of research then analyzed and compared based on the current ongoing reality and then tries to provide problem solving. ${ }^{7}$

Primary research data mostly uses the words of the informant, both orally and in writing. There are two kinds of sources, namely from the author and several other informants. Including Ustadz Achmad Rochani as one of the preachers in Lengkong Sukorejo Village, Ponorogo. Data collection activities were carried out using in-depth interviews, passive role observation and documentation methods. The research location is in Lengkong Village, Sukorejo District, Ponorogo Regency, East Java Province. While secondary research data is data that provides direct information. In the form of books, archives, scientific articles and documentation

\footnotetext{
${ }^{6}$ Ali M Aziz. Ilmu Dakwah, Jakarta: Prenada Media Group, 2016.

${ }^{7}$ Lexy J Moleong. Metode Penelitian Kualitatif. Bandung: Remaja Rosdakarya, 2015.
} 
related to the communication of the Prophet's da'wah with its relevance to modern society.

This village was chosen because the community is relatively rural but is literate with technological modernization, so that some religious activities can be used effectively using advanced technology. In data analysis, the researcher uses 3 components, namely data reduction, data display, and conclusion drawing and verification. To obtain the validity of the findings, the authors carried out four data validity techniques, namely credibility, transferability, dependability and confirmability.

\section{DAKWAH COMMUNICATION STRATEGY}

Communication strategy is a combination of communication planning (communication planning) with communication management (communication management) to achieve the goals that have been set. To achieve this goal, the strategy must be able to show how its practical operations should be carried out. In the sense of the word that the approach (approach) can be different at any time depending on the situation and conditions. So thus the communication strategy is the overall planning, tactics, methods that will be used to facilitate communication by paying attention to all aspects of the communication process to achieve the desired goals. ${ }^{8}$

Communication strategy can be interpreted as a strategy that provides a framework that contains a combination of communication activities that can cause changes in the knowledge, opinions, attitudes, beliefs or behavior of the target community that are important for solving problems within a certain period of time and using certain resources as well. ${ }^{9}$ Da'wah is a speech act that is wrapped with divine messages as the main message. The success of da'wah as a communication activity that focuses on the transformation of religious behavior in society cannot be separated from the language aspect. Islam teaches a universal language in preaching as enshrined in the holy book of the Qur'an. The characteristics of da'wah language

\footnotetext{
${ }^{8}$ Permana, R. Strategi Komunikasi Dakwah Band Wali dalam Lagu Cari Berkah. Jurnal Komunikasi Islam: Vol. 3 No. 1, 2013. p. 124.

${ }^{9}$ Azizah, S. Strategi Komunikasi Pembinaan Pembudidayaan Kambing Boer untuk Meningkatkan Taraf Ekonomi Masyarakat di Desa Wonosari, Kecamatan Wonosari, Kabupaten Malang, Provinsi Jawa Timur. Jurnal Ilmu Komunikasi: Vol. 7 No. 1, 2010. p. 81.
} 
as taught in the Qur'an is to convey good things so that these teachings can enter the hearts of listeners. ${ }^{10}$ Communication skills need to be mastered by a messenger (da'i) in order to be able to ensure that the meaning conveyed can be understood by the listener. In other words, the need to understand the psychology of motivation, behavior and stimulation of the target will help smooth influence madh'u.11

The da'wah communication strategy is an effective and systematic plan of the communicator (da'i) to change the behavior of the communicant (society) in accordance with Islamic teachings. In relation to Islamic da'wah, da'wah communication strategy is the expertise of a da'i in dealing with something, related to the methods and approaches used to achieve something, and has an identifying basic character, and is not apologetic. For this reason, in the process of carrying out the da'wah communication strategy, of course the sensitivity of reading the situation, the character of the communicant (listener) by the preacher will have a significant impact. Elements that must be considered in formulating a communication strategy are the introduction of audiences, messages, methods, media, and communicators. Another source states that strategy is an overall approach related to the implementation of ideas, planning and execution of an activity within a certain time. ${ }^{12}$

One of the important theories in understanding the process of da'wah communication strategy is the theory of diffusion of innovation. Diffusion is the process by which an innovation is communicated through certain channels over a period of time, among members of a social system. Messages disseminated in the communication process contain ideas, or practices that are new or considered new. Diffusion is an innovation medium used by agents of change when trying to persuade someone to adopt an innovation. So that it can be called, diffusion is a special type of communication that contains messages about new ideas.

10 Kholidah, L.N. Kontekstualisasi Bahasa Qur'ani Dalam Komunikasi Dakwah: Strategi Tindak Tutur Transformasi Pesan- Pesan Keagamaan. Jurnal Bahasa dan Seni, Vol. 42 No.1, 2014. p 1.

11 Ahmad Fauzi, et, all. Strategi Pemujukan dalam Komunikasi Dakwah Masyarakat Orang Asli. Jurnal Fikiran Masyarakat: Vol. 5 No.2, 2017. p 82.

12 Sudarman, A. Strategi Komunikasi untuk Meningkatkan Kesadaran Masyarakat dalam Membayar Zakat Maal, dalam Jurnal Communicatus: Jurnal Ilmu Komunikasi: Vol. 2 No. 1, 2018. p 39. 
QAULAN, Vol. 2, No.2, Desember 2021

Zaimatul Millah, Communication Strategy....

There are 4 stages in the innovation diffusion process, namely: innovation, communication media, time and social system. An innovation is an idea, practice or object that is perceived as something new by the individual or group that adopts it. The novelty of an innovation does not depend on being objectively completely new, but if an idea seems new to someone then it is an innovation. A person can know about an innovation some time in advance, but he has not made up his mind, neither supports it, nor adopts it or rejects it. This means that innovation is not limited to knowledge that is completely new to someone. Everett M Rogers assumes that there are at least 4 stages in an innovation adoption process, namely Knowledge, Persuasion, Decision and Confirmation. ${ }^{13}$

\section{PROPHET MUHAMMAD}

Muhammad was born in Mecca who adhered to the belief in statues and idols (hereinafter referred to as paganism). This belief is a belief that has been passed down from generation to generation, including the ignorant culture (hereinafter referred to as the Jahiliyah era). ${ }^{14}$ Beliefs and traditions that have long and strong roots in the people of Mecca, resulted in Muhammad's preaching always getting challenges and obstacles from the infidels and the people of the book. ${ }^{15}$ Not a few insults, ridicule, bad treatment and even expulsion, boycott, and murder of Muhammad and his little friends often occur.

The factors that cause infidels and people of the book to be reluctant to accept the teachings of Muhammad SAW are: first, religious interests, meaning that religion is a sensitive part of every human being. Religion cannot be replaced by a

${ }^{13}$ Bustanol Arifin. Strategi Komunikasi Dakwah Da'i Hidayatullah dalam Membina Masyarakat Pedesaan. Communicatus: Jurnal Ilmu Komunikasi Volume 2 Nomor 2 Tahun 2018. p. 165.

14 The meaning of ignorance is the age of ignorance, darkness, the absence of a light of guidance that leads to the values of beauty. The opposite of jahiliyah is civilized, beautiful and does not appear deviant behavior in terms of values, social norms and religion. During the era of ignorance, slavery, discrimination, injustice, and often did not know good and bad, all based on worldly desires and interests.

15 People of the Book are people who have the holy book. In particular, the term "Ahl al-Kitab" is used to refer to adherents of religions before the advent of Islam. They have revealed holy books such as the Gospel, the Torah, and the Zabur, which were revealed to the apostles or prophets. But the adherents of the religion in question, seem more focused on the Jews and Christians. Jumhur (majority) of scholars agree that these two adherents of religion are declared as people of the book. See Ensiklopedi Islam. p. 77. 
new religion unless there is an awareness that the old religion no longer provides spiritual satisfaction. Rejection will be made to anything and anyone who tries to replace their religion. Therefore, religion for every individual is important and becomes a guide in life and life. For the infidels of Mecca, the arrival of a new teaching brought by Muhammad SAW was a threat to the existence of the religion he adhered to. The teachings of Muhammad SAW are to replace their previous beliefs that are already deeply rooted in their minds. ${ }^{16}$

Second, political interests, meaning that humans cannot be separated from their political life. Politics is a way for a person to strengthen his presence in the midst of society. Through politics, a person will be able to become a ruler, regulate and direct others. There are many ways to get involved in political activities, one of which is to become an influential person in front of the community; whether through economic, social, cultural, even "prophet". For the people of Mecca, Muhammad's new profession invited many people to convert to Islam, automatically threatening their previous rule which had gained mass power and influence. Therefore, the existence of Muhammad SAW greatly threatens their strategic position.

Third, economic interests, meaning that the economy is the reason for competition and hostility between one another. Economic interests are related to the needs of human life to fulfill clothing, food and shelter. The ways to fulfill this need are to keep their old job before they get another, more promising job. They will not accept and agree when their work area as the foundation of their life is disturbed by anyone.

For the pagan society, the work of making statues was a promising profession because there would be many orders for making statues for everyone who worshiped him. On the other hand, if paganism is considered no longer relevant and must be replaced with a new worship, namely the unseen essence of Allah SWT, it will threaten their income. These three factors became the reason for the boycott

16 Enung Asmaya. Implementasi Metode Dakwah Islam Ala Nabi Muhammad SAW di Indonesia. (Jurnal Komunika, Vol. 8, No. 2, Juli - Desember 2014). p. 229-230. 
and torture of the infidels of Mecca to Muhammad SAW for his struggle in the da'wah of Islam at that time. ${ }^{17}$

The da'wah of Muhammad SAW in the Mecca period led to the following da'wah map: first, the da'wah approach was carried out clandestinely (da'wah bi sirr). Da'wah in Mecca by strengthening his family and closest friends called assabiquna alıawwalun are: Khadijah (wife), Abu Bakr (his best friend since childhood), Ali bin Abi Talib (his cousin who is only 10 years old) , Umm Aiman (Muhammad SAW's caregiver since his mother was still alive) and Zaid bin Harisa (his former slave who became his adopted son).18

Some of these friends accepted Muhammad's da'wah and then they developed it to other friends, then there were more and more Muslim converts. Abu Bakr himself later succeeded in converting several of his close friends to Islam, such as: Usman bin Affan, Tholhah bin Ubaidilah, Zubair bin Awam, Saad bin Abi Waqas, Abdurahman bin Auf, and Zubair bin Awwam. Bi-าsirr da'wah, is very effective in reaching the hearts of those who are close to his heart (his family and friends).

Second, the message of da'wah focuses on improving faith/belief. Messages that tell about God who must be worshiped (Allah SWT) and Muhammad SAW in accordance with the teachings brought by Prophet Ibrahim a.s, Prophet Nuh a.s, Prophet Musa a.s and Prophet Isa a.s). This is done because the unity of Allah SWT (tauhidullah) is the main mission of the prophets. Akidah becomes a guide in one's thoughts, words, and actions. In Islam, aqidah is defined as i'tiqadun bil jannani, wa nuthqun bi orali, wa 'amalin bil arkaani. Therefore, aqidah becomes the foundation in carrying out life and life, in the economic, political, social, and cultural fields. Aqidah becomes the orientation and guide of human life, because starting in Mecca Muhammad SAW developed the mission of monotheism. ${ }^{19}$

17 Thohir, Umar Faruq. "Yurisdiksi Hukum Islam dan Implementasinya; Telaah Konsep Dzimmi dalam Masyarakat Hukum pada Piagam Madinah." Istidal: Jurnal Studi Hukum Islam 2.2 (2015): 150-162.

${ }^{18}$ Badri Yatim, Sejarah Peradaban Islam Dirasah Islamiyah II (Jakarta: Raja Grafindo Persada, 2011). p. 87.

19 Etymologically (lughat), aqidah is rooted from the word 'aqada, ya'qidu'aqdan,'aqidatan. 'aqdan, means knot, bond, agreement, and firm. Once formed into 'aqidah means belief. The relevance between 'aqidah and 'aqdan is that belief is firmly tied in the heart, binding, and contains an agreement. 
Third, the da'wah media used by Muhammad SAW when preaching in Mecca was the traditional media in the form of bait al-arkam (Arkam's residence). This media became a means for Muhammad's da'wah when the infidel community found out about his da'wah activities. Fourth, the da'wah method used is bil wisdom and mauidzah hasanah. This method is carried out because the people who are closest to him are known to have knowledge and experience of his religion. Giving good advice and uswah hasanah became an effective method in the da'wah of Muhammad SAW. The interest of family and friends because Muhammad SAW has a person who can be trusted and never lies (positive credibility).

Da'wah in Mecca is different from da'wah when Muhammad SAW was in the city of Medina. The city of Medina became the reason for Muhammad SAW to continue his preaching, because in that city there were already some Muslims residing (the Ansar) and there was a king of Medina named Raja Negus who was willing to accept the arrival of Muhammad SAW and his entourage (the Muhajirin) to live and be together in the city of Medina. Medina. The da'wah process in Medina was relatively short (10 years compared to the 13-year period of da'wah in Mecca). ${ }^{20}$

Muhammad SAW's da'wah strategy while in Medina, were: First, Muhammad made the state of Medina the center of Islamic da'wah. That is, Muhammad as a religious leader as well as a leader of the state, apart from being an apostle he is also a servant of the administration of the people. Muhammad SAW was not only good at convincing the Islamic faith but also good at providing government services and consultations. During Muhammad's reign, many economic, political, and cultural interests had to be disseminated to the entire population. Second, fostering relationships with fellow Muslims (ukhuwah Islamiyah). Brotherhood among Muslims is really considered in order to keep the Islamic da'wah in Medina going. This is understandable because while in the city of Medina, the Ansar and the Muhajirin often have different opinions and interests.

Third, brotherhood between Muslims and non-Muslims (ukhuwah insaniah). This brotherhood is intended so that relations between Muslims and non-Muslims are maintained well, there is no war and actions that disturb the stability of Medina.

20 Thohir, Umar Faruq. Motivasi Jama'ah Lembkota Semarang dalam Mengikuti Pengajian Tasawuf. Diss. IAIN Walisongo, 2013. 
They are given the freedom and protection to practice their religion according to their respective beliefs. Fourth, build the Prophet's Mosque. The construction of the mosque as a symbol of a meeting place for Muhammad SAW and the people of Medina in completing and planning Islamic da'wah in the future. Therefore, Muhammad's da'wah between Mecca and Medina became the inspiration for da'wah for the missionary rijal in the Islamic world. ${ }^{21}$

\section{MODERN ERA SOCIETY}

Islam and modern society have always been an interesting issue to be discussed. For the Muslim community, Islam is not just an actual religion in a series of rituals of worship or the acknowledgment of its adherents to believe in Allah swt as God Almighty and Creator of the entire universe. Islam with its main source of the Koran and Hadith is also a way of life for all its adherents in life. Islam contains the values of life to maintain balance in the sacred relationship between oneself (humans) and their relationship with Allah SWT and the universe.

The modern term that refers to all things that are new, smells of technology and the development of science has presented various rapid developments in shaping people's mindsets and lifestyles. Etymologically, the word modern is Latin "Modernus" which is formed from two words "modo and ernus" which refer to the meaning of the present time period. That is, modern is related to everything new that is different from something old, for example in the way of life, and human activities that are different from the previous period. Martono also mentions the term modernization, which is a process of changing from the old state (traditional) to the new state (modern). In the Indonesian Dictionary, the term modern means attitudes and ways of thinking and acting according to the demands of the times. ${ }^{22}$

Comte, a physicist from France, said that the characteristics of the new order (modernity) in a society include: the concentration of labor in the urban center (city), the organization of work that is determined based on effectiveness or profit, the application of science and technology in the production process. , the emergence of hidden or real antagonism between the owners of capital and workers, the

${ }^{21}$ Enung Asmaya. Implementasi Metode Dakwah Islam Ala Nabi Muhammad SAW di Indonesia. p. 228-231.

${ }^{22}$ Kamus Besar Bahasa Indonesia. p. 1035. 
development of social inequality and injustice, as well as an economic system based on business and open free competition. ${ }^{23}$

Modernization has now penetrated into every aspect of life in society, the emergence of areas of rural and urban communities that are identical with industrialization, the emergence of capitalism which gives birth to economic actors who tend not to pay attention to the balance of the universe, profit is the main goal. Everything is always oriented towards material and power without paying attention to human values. Even in religious life, people can now arbitrarily access everything about religious knowledge that is less relevant, without being known and seeking first the source of its authenticity and often cannot be accounted for for its authenticity.

Modernization has become a symbol of the development of science and technology where there are many new things that make it easier, easier, and accelerate the way people work in all aspects of life. Of course, this development is a positive thing if it makes the steps easier and makes human work more effective with more satisfying results. Modernity is actually a necessity in the development of human life on earth. Allah who has created humans with the gift of reason to enable humans to develop with the ability to think to manage the earth and its contents. The development of science and technology is a proof that Allah SWT has created the human mind so that it can potential it through various human works in aspects of life for the prosperity of human life itself. ${ }^{24}$

Thus, it should become a human awareness of the greatness and majesty of Allah swt, of the infinite, all of His creations inspire and stimulate the human mind to work and always spread goodness by utilizing technology, preaching for example. The era of modernization on the one hand has a positive impact on the advancement of ways of thinking and the development of science that can simplify and streamline human work, wide open information and knowledge so as to educate the public. But on the other hand, its negative impact cannot be ignored because there are still many tendencies of some people who see the modernity side of things that smell like

23 Martono. Sosiologi Perubahan Sosial. p. 82.

24 Yuliatun Tajuddin. Islam dan Masyarakat Modern dalam Sistem Modeling Masyarakat Jawa (Jurnal STAIN Kudus: Volume 1, Nomor 1, Juni 2016). p. 38-39. 
QAULAN, Vol. 2, No.2, Desember 2021

Zaimatul Millah, Communication Strategy....

technology and new lifestyles without paying attention to their effects on psychological development and their moral impact in the midst of people's lives.

\section{DISCUSSION}

The development of the times also has a big impact on the continuity of life today. Because the role of technological sophistication participates in providing convenience changes in all aspects. In the past, da'wah could only be done from house to house or it could be heard in the pulpit of the mosque or musholla during certain activities. However, the modern era adds to the function of preaching using technology, which is used by da'i in spreading the teachings of Islam. For example, through electronic TV or radio, also through social media such as Youtube channels, Instagram and even Whatsapp messages or stories that are used to share and invite goodness.

Even though the times are developing, the existence of da'wah during the time of the Prophet Muhammad is still a reference for da'i in spreading Islam. The implementation of the da'wah of the Prophet's time is still relevant to modern society. Because the da'wah of the Prophet is known for being friendly and not forcing and da'wah that can see how the social situation of the people is. The goal is to keep the community well and effectively accepted, so da'wah communication is now utilizing social media. So that people can adjust themselves well and can actualize themselves (self-actualizing).

The communicator or a da'i in his da'wah opportunity always gives messages that can be gleaned from the content of the discussion theme. Usually the message of da'wah contains the delivery of information on Islamic teachings in the form of an invitation to do good and prohibition of doing evil. All of this functions as social control, correction of incorrect understanding of religious teachings, deviant attitudes and behavior. Therefore, da'wah cannot be separated from a goal. The main goal is to overcome the important and complex problems faced by the Ummah, including problems that may weaken the faith and piety of Muslims. With the sophistication of today's technology, it will make it easier for people in the modern era to find a way out of the problems they face. The benefit is that the community can solve problems that occur at any time in their environment, such as an incorrect understanding of religious teachings. 
From the description above, as the relevance of da'wah is a solution to the problems of the people. The relevance is even more significant if the da'wah is carried out professionally and proportionally, covering all levels of society. That is, da'wah must be packaged in such a way as to influence people's perceptions that the values of Islamic teachings are higher in value than other values so that da'wah must be able to present Islam as Rahmatan lil al-'alamin.

The existence of religious figures can be leaders who can direct and guide the community in dealing with various phenomena that can be troubling and divide the people. Especially in the midst of a society which incidentally is a religious community, the presence of religious leaders is like a religious leader who can translate the meaning of the principles of virtue and goodness in religious teachings, their realization in the midst of life.

Religious figures who are pinned on a Ulama, Kyai, Ustadz, Mubaligh to Da'i are personal figures who have the ability to preach with their abilities and strengths to master the field of religion both theoretically and practically. Religious leaders play a very important role in maintaining the ethics and morals of the community based on the principles of religious teachings. Geertz in his book reveals that religious leaders often play a role in resisting the flow of change while also actively encouraging change in the name of religion. ${ }^{25}$

During the time of the Prophet Muhammad, his presence really became a leader in all areas of life. Various community problems at that time would be resolved after consulting and discussing with the Prophet Muhammad. With the basis of religion, the problems of people's lives can be resolved and the people feel how Islam is a guide for human life (way of life). The personal figure of the Prophet Muhammad himself is a figure whom Allah has bestowed light (Nuur) which psychologically binds and shapes the beliefs of the people. Allah SWT has said that in the Messenger of Allah, there is a good example (uswah hasanah) for people who hope for His mercy. ${ }^{26}$

${ }^{25}$ Clifford Geertz. The Religion of Java, terj. Aswab Mahasin dan Bur Rasuanto dengan judul Agama Jawa: Abangan, Santri, Priyayi dalam Kebudayaan Jawa. (Cet.1, Jakarta: Komunitas Bambu, 2013). p. 134.

26 "Indeed, the Messenger of Allah has in you a good role model for you (that is) for those who hope for (the mercy of) Allah and (the coming of) the Day of Resurrection and call upon Allah a lot." (Al-Ahzab [33]: 21) 
Rural communities are still regarded as standards and maintainers of the social life system and indigenous culture in the form of mutual help, community, brotherhood, mutual cooperation, art, religious observance, personality in dress, customs, moral life, and other cultures that come from the outside. compared with the original culture which generally still prevails in rural areas to examine the benefits and harms of the new culture. However, along with the development of science and technology followed by very rapid means of information and communication, some of humanity, especially rural communities, experienced a shift in values and began to lose their identity. Moral decadence caused by the recognition of western culture as a trend which, if followed, will gain social respect and place among certain people.

This can be seen from several cases where the traditional dress of women in rural areas is not much different from women in urban areas who have a very tight appearance and show their genitalia and curves. In addition, the level of participation of rural communities in recitations and congregational prayers at the mosque is decreasing because they are busy with soap operas and television shows, as well as the condition of children who prefer to hang out in front of the TV and the internet rather than attend prayer rooms and Islamic boarding schools.

The above phenomenon can also be found in Lengkong Village, Sukorejo District, Ponorogo Regency, which in fact is a rural community. Rural communities in Sukorejo sub-district, Ponorogo district, tend to follow the modern lifestyle that comes from the west. One of the reasons is the massive amount of information obtained through mass media channels and the internet.

In this paper, the author wants to raise the figure of a da'i in starting and carrying out the history of the da'wah movement. Then analyzed according to the implementation of the da'wah of the Prophet SAW. Ustadz Achmad Rochani (da'i) is an ustadz teacher of the Koran at the An-Najiyah Lengkong Islamic boarding school, Sukorejo, as well as an observer for memorizing the Koran bin-Nadzor and at the same time a preacher in his environment, namely Lengkong Village, Sukorejo District, Regency Ponorogo since 12 years ago or in 2008 to be precise. He is known 
as a "hijrah youth" or preacher who gives tausiyah or lectures in mosques and prayer rooms around Lengkong village, Sukorejo, Ponorogo. ${ }^{27}$

Even though he feels that knowledge is still limited, according to him spreading kindness is our obligation as the people of the Prophet Muhammad in continuing da'wah activities to the community. Especially the common people who do not know the Prophet as a role model for Muslims until now. However, modern society does not easily accept what is conveyed, we as people who understand religion because we have studied religion for years must be able to adapt to the conditions of society so that people can apply the goodness of the da'wah that is conveyed to everyday life. So da'wah can be accepted by the wider community by utilizing the sophistication of today's technology. Indeed, we cannot close our eyes, the rapidity of technological sophistication needs a filter so that it can have a positive impact on ourselves and others. Here the need for the role of a preacher who continues the values of preaching goodness to modern society in addition to Islamic activities in the village environment, also by carrying out da'wah activities through cyberspace. You can stream Youtube, Instagram, and even broadcast Whatsapp messages.

There are several similarities in da'wah communication that he is implementing now in accordance with the da'wah of the time of the Prophet Muhammad. First, the message of da'wah focuses on improving faith/belief. The content of the da'wah message that the da'i presents is actually light and attractively packaged so that the congregation does not get bored with his da'wah, which is in accordance with the problems that Muslims often face. Related to increasing monotheism to Allah SWT with sunnah practices, serving parents by always praying for them, the virtue of giving charity, doing good deeds and others. Often he preaches with the theme of the stories of the Prophet, companions or previous events by comparing them with current reality for the material to be presented. Such as the commemoration of the Prophet's birthday, Muharram or the Islamic new year, Rojaban, Isra 'Mi'raj etc. This is done because the unity of Allah SWT (tauhidullah) is the main mission of the prophets. Of course it does not change the essence of the goal in the modern era now.

${ }^{27}$ Interview with Ustadz Achmad Rochani, one of the da'i in Lengkong Village, Kec. Sukorejo Kab. Ponorogo, on November 21, 2020 at 18.30 WIB. 
Second, with the da'wah material, the da'i performs verbal da'wah communication (bil al-lisan), meaning that da'wah is carried out by speech, an invitation through his lecture. With that people will feel the need for religion, because da'i are able to process da'wah messages that contain Islamic values according to current reality. The things he conveys through cannot be separated from the values of amar ma'ruf nahi munkar (inviting goodness and preventing evil). Because the key or the most important purpose of preaching is this. And as time goes by, our faith and devotion to Allah increases.

Third, the da'wah media adapts to the modern era by utilizing technology. Not only through the pulpits of the mosque or prayer room, da'wah can be done through social media. Like Ustadz Rochani, he also calls for da'wah with WhatsApp social media, through stories or pictures that contain elements of Islamic religious values. Then people will be moved by the message of da'wah contained, which initially people accidentally saw the story, will feel that the message can be useful for them.

Fourth, the da'wah method used to convey Islamic teachings to rural communities is bil wisdom and mauidzah hasanah. That this method was also used by the Prophet to people who already believed in the Prophet as the messenger of the religion of truth, namely Islam. Ustadz Rochani (da'i) also gave good advice and uswah hasanah as an effective method. His guideline is to apply the values of religious teachings first in daily life before he conveys and invites others. The perspective is "let people know and judge my daily personality first, then it can be imitated or not". This includes non-verbal da'wah communication (bil-hal). This is what can be a reflection of us, not just patronizing by telling people to do good, but we are the first to spread kindness to others.

Interestingly, Ustadz Achmad Rochani, who has now entered the age of almost half a century, is a memorizer of the Qur'an or tahfidz al-Qur'an 30 juz. Even though he graduated from high school / equivalent, he did not stop his intention to call for Islamic values by preaching. Armed with a boarding education for approximately 10 years. He is able to be trusted by the community as a da'i who has 
a light da'wah communication style according to behavior in his daily life. Prioritizing uswah hasanah as a guide for reasons in preaching. ${ }^{28}$

For a religious figure, a da'i, preaching is not limited to conveying and inviting Islam, but also how to show the contextualization of Islamic values in life. Preaching also means communicating Islamic values in everyday life. Thus the community or mad'u will be able to feel directly the realization of Islamic values in the midst of the realities of life. ${ }^{29}$

Actually, the existence of religious leaders in each era does not have a different role and responsibility for the people. Since the first example of the Prophet SAW how to be a leader until then continued by his friends, scholars, even in this modern era, the existence of religious figures is still awaited by the community. It has become a human psychosocial need in a community the importance of a leader, including leaders in the religious field. Even a leader in the field of religion in the midst of a religious community becomes a strategic thing to drive a change and community development for the progress of the nation and state. Especially in the midst of the complex and pluralistic diversity of people's religions and cultures such as in Indonesia, the role of religious leaders as leaders will be a very decisive position to control and direct society so as not to fall into confusion and controversy that occurs due to the variety of differences.

Thus, we can study the role of religious leaders in people's lives, not only in the practice of worship in the religious field. The role of religious leaders can be mentors, advisors, counselors, motivators, and enlighteners for the people they lead. In the midst of the life of a religious community, they still strongly believe that religious principles can be the basis of reference in solving a problem. Al-Quran and hadith have provided many principles and examples or life stories that can be an i'tibar for the problems of people's lives in this era. However, not all people can translate and understand its actualization in the midst of modern life. So, it is the religious leaders who have the ability and expertise to translate the holy verses of the Koran and the messages in the hadith of the Prophet, contextualizing them with the problems of people's lives.

28 Interview with Ustadz Achmad Rochani, one of the da'i in Lengkong Village, Kec. Sukorejo Kab. Ponorogo, on November 21, 2020 at 18.30 WIB.

${ }^{29}$ Faizah et. all,. Psikologi Dakwah (Jakarta: Prenada Media, 2015). p. 196. 
QAULAN, Vol. 2, No.2, Desember 2021

Zaimatul Millah, Communication Strategy....

\section{CONCLUSION}

In connection with the above description, it can be concluded that the existence of Islam today is inseparable from the da'wah activities brought by the Prophet Muhammad. The development of the times has brought people to be smarter in acting and thinking. With the sophistication of technology, people can use it to call for goodness by preaching that is thick with da'wah messages with Islamic values according to today's reality. Like the da'wah communication carried out by Ustadz Achmad Rochani to the people of Lengkong Village, Sukorejo Ponorogo District. He as a preacher focuses on inviting goodness by imitating the Prophet's da'wah, namely with Uswah Hasanah, giving an example first rather than ordering to do good. Then preach with light material but according to the needs of the community and don't forget the da'wah communication that he does also by utilizing the sophistication of today's technology. That way the people of Lengkong Village responded well to the da'wah carried out by him.

In the modern era, it turns out that the reality of da'wah is still relevant if you reflect on the phenomenon of da'wah during the time of the Prophet Muhammad. It's just that now the sophistication of technology adds to the ease of preaching. The goal is when da'wah is accepted by modern society and people are able to apply da'wah values in everyday life. So that the role of religious leaders can be guides, advisors, counselors, motivators, and enlighteners for the people they lead. In the midst of the life of a religious community, they still strongly believe that religious principles can be the basis of reference in solving a problem.

\section{REFERENCES}

Arifin, Bustanol. Strategi Komunikasi Dakwah Da'i Hidayatullah dalam Membina Masyarakat Pedesaan. Communicatus: Jurnal Ilmu Komunikasi Vol. 2, No. 2, 2018.

Arif, Muhammad. Urgensitas Pesantren Dalam Inovasi Pendidikan. Kediri: IAIN KEDIRI PRESS, 2019.

Asmaya, Enung. Implementasi Metode Dakwah Islam Ala Nabi Muhammad SAW di Indonesia. Jurnal Komunika: Vol. 8, No. 2, Juli - Desember 2014.

Azizah, S. Strategi Komunikasi Pembinaan Pembudidayaan Kambing Boer untuk Meningkatkan Taraf Ekonomi Masyarakat di Desa Wonosari, Kecamatan Wonosari, Kabupaten Malang, Provinsi Jawa Timur. Jurnal Ilmu Komunikasi: Vol. 7 No. 1, 2010.

Aziz, Ali M. Ilmu Dakwah. Jakarta: Prenada Media Group, 2016. 
QAULAN, Vol. 2, No.2, Desember 2021

Zaimatul Millah, Communication Strategy...

Departemen Pendidikan Nasional. Kamus Besar Bahasa Indonesia. Jakarta: Balai Pustaka, 2011.

Faizah et all. Psikologi Dakwah. Jakarta: Prenada Media, 2015.

Fauzi, Ahmad et., all. Strategi Pemujukan dalam Komunikasi Dakwah Masyarakat Orang Asli. Jurnal Fikiran Masyarakat: Vol. 5 No. 2, 2017.

Geertz, Clifford. The Religion of Java, translated by Aswab Mahasin dan Bur Rasuanto dengan judul Agama Jawa: Abangan, Santri, Priyayi dalam Kebudayaan Jawa. Cet.1, Jakarta: Komunitas Bambu, 2013.

Ilaihi, Wahyu. Komunikasi Dakwah. Bandung: PT. Remaja Rosdakarya, 2010.

Kholidah, L.N. Kontekstualisasi Bahasa Qur'ani Dalam Komunikasi Dakwah: Strategi Tindak Tutur Transformasi Pesan- Pesan Keagamaan. Jurnal Bahasa dan Seni, Vol. 42 No. 1, 2014.

Martono, Nanang. Sosiologi Perubahan Sosial. Jakarta: PT. Rajagrafindo Persada, 2012.

Marwantika, Asna Istya "TREN KAJIAN DAKWAH DIGITAL DI INDONESIA : SYSTEMATIC LITERATURE REVIEW," Proceeding of Conference on Strengthening Islamic Studies in The Digital Era 1, no. 1 (2021): 249-65, https://prosiding.iainponorogo.ac.id/index.php/ficosis/article/view/37.

Permana, R. Strategi Komunikasi Dakwah Band Wali dalam Lagu Cari Berkah. Jurnal Komunikasi Islam: Vol. 3 No.1 , 2013.

Rahmawati, Istina. Potret Dakwah di Tengah Era Globalisasi dan Perkembangan Zaman. AT-TABSYIR, Jurnal Komunikasi Penyiaran Islam: Vol. 1, No. 1, Januari - Juni 2013.

Sudarman, A. Strategi Komunikasi untuk Meningkatkan Kesadaran Masyarakat dalam Membayar Zakat Maal. Jurnal Communicatus: Jurnal Ilmu Komunikasi, Vol. 2 No.1, 2018.

Tajuddin, Yuliatun. Islam dan Masyarakat Modern dalam Sistem Modeling Masyarakat Jawa. Jurnal STAIN Kudus: Vol. 1, No. 1, Juni 2016.

Tasmara, Toto. Komunikasi Dakwah. Jakarta: Gaya Media Pratama, 1987.

Yatim, Badri. Sejarah Peradaban Islam Dirasah Islamiyah II. Jakarta: Raja Grafindo Persada, 2011. 